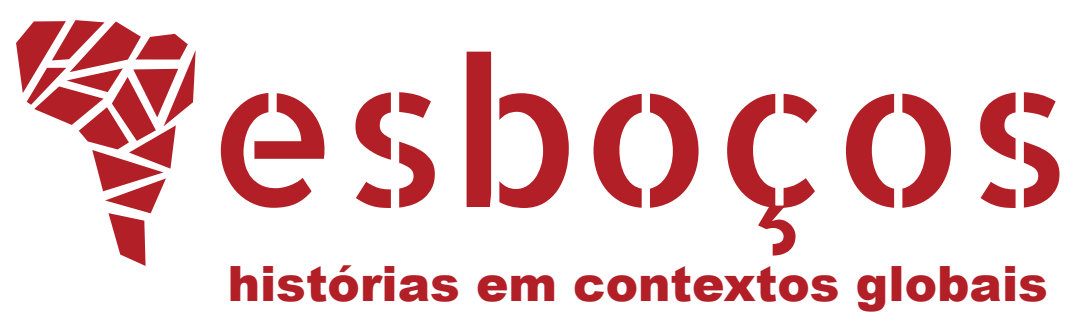

\title{
MAKING THE LEAP: COMMODITY \\ CHAINS AND THE POTENTIAL \\ FOR GLOBAL ENVIRONMENTAL \\ HISTORIES OF CAPITALISM
}

Jack Bouchard

(1) https://orcid.org/0000-0001-8139-9508 Email: jack.bouchard@rutgers.edu

a Rutgers University New Brunswick, School of Arts and Sciences, Department of History, New Brunswick, NJ, USA

\section{DEBATE}

Colapso ambiental e histórias do capitalismo 


\section{ABSTRACT}

This article is a brief response to Leonardo Marques' essay "Commodity Chains and the Global Environmental History of the Colonial Americas." It focuses on the practical and theoretical limitations of commodity-chain histories as away to address our political and environmental moment. It argues that commodity-chain histories must overcome the complexity of their subjects, and leap the theoretical gap between local and global scales without losing sight of nature. To do so, the article advocates for more work by environmental historians, and a focus on transformation rather than commodity flows.

\section{KEYWORDS}

Commodity Chains; Environmental history; Atlantic history. 
I t has become eminently fashionable, of late, for political figures to quote some variation of Seamus Heaney's famous line "once in a lifetime...hope and history rhyme" (1990). ${ }^{1}$ For many of us still waiting for the hope, we are instead increasingly living through a moment when politics and scholarship rhyme. Our historical research, no matter how niche, has become inextricably bound up with our political moment. We are faced with the stark reality of environmental upheaval, industrial capitalism and globalization. The result has been, in academia, and explosion of work in environmental history, the new history of capitalism, and global/world history. The need to historically contextualize and explain contemporary crises has never seemed more pressing and (we may hope) rewarding.

And yet, trapped as we all are as participants in a real-time environmental crisis brought about by the maturation of industrial capitalism, it is rather ironic, as Leonardo Marques has noted in his essay "Commodity chains and the global environmental history of the colonial Americas," that historians have singularly struggled to confront and reconcile environmental histories with our understanding of global capitalism. If "The accumulated evidence of this global environmental collapse shows not only the failure of a modernizing project, but also calls for an approach that can effectively integrate the systemic dimensions of our past and present problems" (MARQUES, 2021 , p. 642), then it is also true that current global history "does not seem prepared to deal with these challenges" (2021, p. 242). It is not merely a matter of bridging these different fields, but of reconciling essential theories and approaches to explain our present moment. It is time for history to learn to rhyme with the times, and to reconcile the robust theoretical work on the history of capitalism with the desire to leap towards global and environmental frameworks. The need to integrate environmental, global, and economic histories has never been more immediate.

In light of this, Marques has presented a timely critique, a well-deserved prod to a field which is in danger of letting an important moment pass. As he puts it, "theorizing capital and capitalism does not eliminate the need to think about its historical development" (2021, p. 649) - let us put the history back in global capitalism. His essay is a stimulating attempt to do just this. He rightly identifies scale, especially scales of time (human, natural, capitalist) as the stumbling block. Marques' solution is to embrace the history of the commodity chain, so as to "understand the plurality of times of capitalism as a historical system and its shifts over time" (2021, p. 647). As he notes, "Returning to the classic uses of the concept of commodity chain can offer a powerful instrument to understand the plurality of times of capitalism as a historical system and its shifts over time" (2021, p. 647). There is much to recommend this approach.

In this essay, I wish to do four things. First, I hope to offer some comments on Marques' contention that global history has proved unable to address the current environmental-capitalist crisis, and to emphasize the need for more global work by environmental historians. Second, I will address the problem of complexity in commodity-chain histories. Third, I and related, I wish to discuss the problems with scaling up from and theorizing from commodity-chain histories. Finally, I wish briefly argue for the need to focus on transformations rather than flows in commodity-chain histories. In general, I am more concerned with practice than with theory. What follows is an attempt to endorse both the critique and the solution Marques has proposed in his

\footnotetext{
${ }^{1}$ Though President Joseph Biden has done this most consistently, he is hardly alone.
} 
essay, while cautioning and nuancing against both a rush away from global histories and towards commodity-chain studies.

\section{GLOBALIZING THE ENVIRONMENT}

In suggesting a renewed focus on commodity-chain histories, Marques is attempting to prod global historians to engage more with the environment. What I would suggest rather is not for global historians to embrace an environmental lens, but rather for environmental historians to embrace the global. Environmental histories are already engaging thoroughly with histories of capitalism, but typically at regional and local scales. ${ }^{2}$ Commodity-chain histories are further a staple of environmental historical inquiries, forming a natural bridge. The time has come for environmental historians to engage more with global and world histories, and with the existing literature on capitalism.

This is the crux of the problem. There is a mismatch between the methods and goals, between assumed frameworks and necessary perspectives. Global historical academia is changing rapidly, but the lag-time between training and output (especially for the kind of robust, theory-informed, synthetic works Marques and others are rightly calling for) has left us wanting. Thankfully, these are all not merely easily solvable concerns, but problems which are already being addressed as more environmental and premodern historians themselves engage with the history of global capitalism. Indeed, one of the benefits of Marques' essay is its value in pointing the way forward for a rising generation of scholars.

The early $21^{\text {st }}$ century has been marked by an historical global turn, and the rise of world-history as a serious approach to the past. ${ }^{3}$ Yet even as more connective, inclusive, and global-scale research and teaching has been embraced by historians, the limitations of this movement have been made clear. Marques rightly identifies the problem as a "cosmopolitan global history that at times resembles a history of globalization" (2021, p. 642). For all too many historians, global history means a history of Europe-in-the-world, or a large-scale economic study masquerading as world history. Crucially, these approaches are rarely able (or unwilling) to integrate natural histories and non-human perspectives into their stories. This forms the basis of Marques' critique of global history, and its inability to reconcile histories of capitalism and the environment. As he puts it, we must "develop a more effective and critical global perspective that manages to incorporate the times of nature" (2021, p. 643).

Although I am sympathetic to these critiques of global history, I think this reading of global history does not sufficiently appreciate the more fundamental, practical problems with how the field has developed. To be blunt, the problems lie with the scholars rather than the scholarship. Global history has grown out of other fields, and its practitioners have almost universally migrated to global perspectives from regional ones. Few if any were trained in global history, but instead began their careers as economic and/or European historians of various stripes. ${ }^{4}$ I don't mean this is a criticism

\footnotetext{
${ }^{2}$ For a good example see Demuth (2019).

${ }^{3}$ Marques notes a number of examples (2021, p. 642-644). As representative examples of a global history de-centered on the global north, see: (ABU-LUGHOD, 1989; HANSEN, 2020; MANNING, 2013; PAINE, 2013; SCOTT, 1998; 2009; WESTAD, 2017).

${ }^{4}$ For the impact of economics on grand historical thinking, see Kim Bowes (2021). Her work rightly
} 
of their scholarship, but rather I think it is important to acknowledge that the training and background of many of these authors has shaped our approach to the history of global capitalism. And it is this shaping which accounts for many of the issues Marques and others have identified. ${ }^{5}$

A further issue is that most of these scholars (especially those Marques notes in his essay) are modernists. They were trained in $19^{\text {th }}-20^{\text {th }}$ century histories, and began their careers on those topics. Perhaps unsurprisingly, for many their interest in global history has treated the mid-eighteenth century as a starting point. This has produced a scholarship which is skewed towards the last 250 years, and which rarely engages with the long durée or natural scales of time. Foreshortened histories of capitalism are rarely as satisfying as those which trace its rise and alternatives in the premodern world. Is this not, after all, one of the enduring values of Wallerstein (1974), Braudel (1982), Arrighi (2010) and Moore (2017)? That they actually try and engage with long histories of capitalism which extend back to the sixteenth century? More so, the hegemony of modernists has shaped our perception of the global environment. Modernists tend to emphasize humans acting upon nature, rather than the kind of dialectical interactions within the human web which are so important. These are old critiques, but are worth revisiting as we enter a time of global crisis armed with books primarily written by those whose interests and assumptions are very recent.

It is further worth stressing that, with the notable exception of Jason Moore, very little of the scholarship on the global history of capitalism has been written by historians of the environment. Most of the scholars Marques points to are trained as economic or imperial historians, or as sociologists; their works have, accordingly, stressed socioeconomic perspectives to the detriment of the environment. Environmental history is, after all, a field which has only recently matured and expanded. It has also been a field which stresses the local and particular, rather than the global and the general (on this, more below). Even grand meta-environmental processes like climate fluctuations or pandemics are easiest to study through a localized lens. We should not, perhaps, be surprised that economic historians trained before the rise of environmental history have paid insufficient attention to nature.

Commodity-chain histories are the way to pull environmental history towards the global, and to compel historians to engage more explicitly with theories of global capitalism. At their core, as Marques recognizes, in commodity histories the naturecapitalism nexus is inescapable. One must confront the structures of capitalism and its relationship to biology, geography and climate in order to explain the movement of commodities. This is one of the insights of Anna Tsing's masterful The Mushroom at the End of the World, which shows how a single type of mushroom can be symbol of, symptom of, and solution to the destructive ecological and social forces of capitalism (TSING, 2015). Her work also reminds us of the need to consider the heterogenous nature of capitalism, and how a multiplicity of capitalist processes and ecologies can exist side by side. By intentionally engaging with the histories of a single commodity, we are compelled to acknowledge these truths.

criticizes the attempts by Scheidel, Maddison and others to apply modern thinking about GDP to the historical development of economic growth and capitalism. (MADDISON, 2001; 2003; SCHEIDEL, 2019).

${ }^{5}$ This is, I think, the implied argument underlying Jeremy Adelman's critique, which Marques cites. Adelman does not address it directly, however (ADELMAN, 2017). 
The focus on commodity-chains may allow us to escape the tyranny of modernism and human scales of time in historical inquiry. Because of their inherent role at the intersection of capitalist processes and natural structures, commodity-chains allow (or even compel) us to engage with fundamental questions of scale. The great virtue of commodity histories, as Marques rightly identifies, is the ability to connect across time and space. "A focus on specific commodities also permits analysis of the ecological, social organizational, and demographic effects both in the region of extraction and in the region where its eventual transformation contributes to the acceleration of production and consumption" (BUNKER, 1985 apud MARQUES, 2021, p. 648). This is both a benefit and a problem, for in linking the local and particular to the global and general there is quite a vast gulf, as noted below. But one of the benefits of histories of commodity chains is the potential to do deep histories, premodern histories, and histories which connect pre-capitalist with capitalism modes of production. This was one of the signal achievements of Sidney Mintz' Sweetness and Power (1985), which traced the long evolution of sugar production and consumption across time and space. ${ }^{6}$ These deep histories allow us to embrace both the time scales of nature and those of humans, and to understand how the conflict between them may lie at the core of our modern environmental crisis.

This is a particularly important aspect of commodity histories inasmuch as environmental history tends to lend itself to embracing small scales. Recent work by environmental histories has stressed the importance of the local, of micro-ecologies, of heterogeneity in how humans interface with nature. ${ }^{7}$ Environmental histories which try to go global tend to be broad catalogues of case studies and sub-fields rather than truly synthetic works. ${ }^{8}$ The recent turn to the Anthropocene has encouraged more scholars to embrace global frameworks, but has also produced a teleology which against results in a modernist bias. More intensive work in commodity-chain histories may be a way to push environmental history to engage with global scales and with the most recent debates about capitalism's origins, without sacrificing the focus on nature, labour and specificity which is so important to the field.

There are other more practical benefits to commodity-chain studies. The kinds of commodity histories Marques suggests would allow us to bring many different research tools to bear. They call for innovate and interdisciplinary methods, for how else could we handle the entanglement of different natural and human interactions and scales? This is yet another reason for environmental historians, who are often already obliged to work in a multidisciplinary format, to embrace global histories of capitalism. Indeed, one of the benefits which Marques doesn't acknowledge is the degree to which commodity histories encourage interdisciplinary, and even collaborative, historical research. They compel us to consider the biology and chemistry of our subjects, the place of climate in shaping production and consumption, and the rule of culture in shaping how humans turn nature into commodities. In order to deal with the complexity of commodity-chains and the need for aggregation, collaborative work may be the

\footnotetext{
${ }^{6}$ For a more recent example, see Gary Okihiro's deep history of pineapple production in Hawai'i (OKIHIRO, 2009).

${ }^{7}$ Note for instance the argument in Horden; Purcell (2000) as a rejoinder to Braudel (1972). See too, as examples: Donahue (2004), Reid (2015).

${ }^{8}$ C.f. McNeill (2000) and Richards (2006). By contrast, note the possibilities of comparative work (using localized case studies) demonstrated in Brown (2001).
} 
easiest and most productive solution. In certain spaces (and here I am thinking of North America academia) historians rarely work collaboratively, but in confronting our environmental-political moment that may no longer be a sustainable worldview.

These three advantages - the ability to connect, the potential for deep histories, and the potential for collaborative-interdisciplinary work - may ultimately be the solutions to the problems which Marques identifies at the start of his essay. They allow us to break free of global histories which have been largely modernist and eurocentric. They allow us to write the kinds of complex, nuanced, far-ranging histories of commodity-chain interactions which do justice to historical reality. These are precisely the kind of works which will allow us to bridge the gap between the local and the global, between commodity-in-nature and commodity-in-world-economy. As I am suggesting, environmental historians are well poised to do just this.

\section{MOVING PARTS}

Why then have commodity-chain histories not already allowed historians to address deep questions of climate, capital and global scales? Marques is right to note that this is an historical approach which is both venerable and niche. Commoditychains have been the subject of some of the most influential works in global history, and yet this approach is rarely deployed systematically to answer fundamental questions of historical structure. In this observation I think Marques is quite correct, but I do not think that he engages sufficiently with the limitations of commodity-chains as a basis for research and analysis, and this is worth examining. We must confront two issues. The first, addressed in this section, is the problem of practice: how do we write commodity-chain histories which are sufficiently complex to provide useful explanatory power? The second, addressed in the following section, is one of theory: how do we reconcile the scales between commodities and global history without losing sight of nature? In considering these issues, I find myself in the odd position of cautioning against commodity histories, as someone who himself works on commodity histories. I do not mean to reject Marques' contention that commodity-chain histories may allow us to overcome theoretical gaps, but rather to suggest ways that this approach can be applied in practice to achieve the laudable goals he lays out for us.

To use a hackneyed but useful metaphor, consider our commodity subject a billiard ball on a table, and the commodity-chain its movement across the table after we have hit it with a pool cue. It is tempting to trace that movement and write a history of our one commodity-ball. Yet to produce a useful, operative history we cannot focus on the trajectory of our single billiard ball; rather, we must be able to explain the simultaneous movement of every other ball on the table, while also understanding the parameters of the table itself. After all, no commodity exists in a vacuum, but is constantly acting with and against other commodities (the other balls) and human/inhuman processes (the cue, the table) as it moves along the chain. Commodities are trapped in webs of consumption and exchange, ceaseless shaping and being shaped by those around them. Each link in the commodity-chain produces second- and third-order effects, from shifting demand or supply of a competing commodity to changing the ecology of a particular part of the world. This is difficult work, requiring an expansive and laborintensive approach to the genre, but the real value of commodity-chains comes from understanding how our commodity changes and is changed by the other commodities 
and natures it collides with. This is the essence of its ability to work with scales of space, time and subject: one ball, all the balls in motion, the whole table together.

Consider the case of codfish. Cod is a well-documented food, which we can trace from ocean to dinner plate as a long commodity chain connecting places like Newfoundland with Iberian tables. Although much good work has been done on the history of this animal-turned-food, most notably by Mark Kurlansky (1997), there has been an unfortunate tendency to study cod alone (BOLSTER, 2014; BOUCHARD, 2018; INNIS, 1940; KURLANSKY, 1997; POPE, 2004; TURGEON, 2009). Some fisheries historians treat cod, and at times alternatively herring, as the only soughtafter fish in the early modern Atlantic. But we should see cod as a food commodity which is in constant competition with other fish, meats and plants. The rise or fall of saltcod production reflects not just ecological and climatological changes in the north Atlantic, but changes in European tastes and fish harvesting elsewhere in the Atlantic. In the sixteenth century, cod competed with alternatives such as hake, sardine, herring, haddock, ling, salmon, eel and anchovy in the market for preserved fish (SICKING; ABREU-FERREIRA, 2009; BARRETT; ORTON, 2016). Fisheries such as those in the Irish Sea, the Algarve, the North Sea and Saharan Africa all successfully competed with and suppressed codfish production in the sixteenth century. Only as the seventeenth century wore on did dry-salted cod displace these rivals not just in Europe but in the Mediterranean and the Caribbean. Cod is also a living organism whose exploitation affects the marine life and ecosystems of the far north Atlantic. The pressure fishworkers applied to cod in the early modern period affected capelin, herring and salmon stocks in places like Newfoundland. Fishworkers devastated local bird populations for food, and dramatically altered the socio-economic structure of Algonkian- and Inuit-speaking communities in the northwest Atlantic (LOEWEN; CHAPDELAINE, 2016; POPE, 2009). Cod fishing contributed to the rise of both commercial whaling in the northwest Atlantic, which devastated whale populations, and the fur trade by the early seventeenth century. All this comes from a single commodity moving along its train from the waters of Newfoundland to the tables of Paris.

As the example of cod suggests, the problem of complexity has been particularly tricky for food historians, an important sub-field within environmental history, who must face two concurrent problems. First, food production requires the input of other commodities (fertilizer, water, labour, equipment, land, etc.) whose availability is in a constant dance with food production. In the case of cod, every fishing ship which produced bacalhau also required an immense ecological investment in the form of timber, food, salt, alcohol, plant fibers, and other commodities. Second, many foods directly compete with each other in ways that can create complex repercussions across local and global marketplaces. The rise in cod consumption in Europe was held back by increased production of competing fish types in European waters like sardines, herring, hake and salmon. If we wish to build upon the work of pioneers like Mintz (which we should and must), we must pay attention to these problems.

It is further the case that commodities are a process, not an end in and of themselves. To mint a silver coin, to build a ship, to harvest sugar cane: these are moments in the history of commodities, but these histories have no endpoint. As commodities proceed through their transformative processes, they require more and more inputs and resources. Each link in a commodity chain is alive and dynamic, such that commodities do not just transform but also consume while moving. Once again, we must confront that web of commodities which makes this so tricky. 
I would draw our attention to the example Marques uses, the ship in the eighteenthcentury Atlantic economy. Ships are not one-off commodities. They must be constantly maintained, both in terms of refitting/repairs and in the constant, massive requirement for provisions and equipment which goes into each voyage (GARDINER, 2013; DAVIS, 2012; HAYES; MATTHEWS; ALLAIRE; HOLM, 2019; PÉREZ-MALLAÍNA, 1998). Indeed, we would be better seeing the ship not as a commodity but as an inanimate consumer, a kind of macro-organism. It must be fed a steady diet of pitch, tar, rope, copper, biscuit, grog, lemons, saltpork and saltcod or it will die. More and more timber must be felled to provide the boards to fix holes and leaks; copper must be mined to replate the bottom of the hull; fibres must be harvested from field and forest to produce new rope and sails. Above all, each and every voyage requires a constant influx of organic energy in the form of preserved food, not just at the start of the voyage but periodically en route. The forests which died to give it life are only the first ecological transformation which allows for the ship-commodity to function. ${ }^{9}$

This constant need for provisioning has tremendous environmental consequences, which often intersect with and expand the forestry problems Marques' notes. ${ }^{10}$ The food must be grown and raised, the pitch and tar must be harvested and refined, the sails and ropes must be grown and woven. All these things require not just labour but land. The humans who work the ship must be taken from land, some directly from farms and forests where their labour could have been applied to growing food and more timber. In short, tackling an historical commodity like the ship requires rethinking what commodities are, and how we study them. Much as we must keep track of how a single commodity-chain impacts other chains with which it collides, so too must we carefully reconstruct how a single commodity consumes and warps a myriad of commodities as it moves through the world. This is the only way to truly understand the environmental impact, and by extension the economic impact, of a commodity-chain.

It is worth pausing to mention that Marques' ship example reminds us of the dangers of separating maritime and terrestrial environments. This was recently and forcefully argued by Liam Campling and Alejandro Colás in their book Capitalism and the Sea (2021). Commodities, even those from clearly terrestrial origins, can't be separated from the sea which moves and sustains them, nor can oceangoing traffic be separated from the landed resources which fuel them. Each ship is a floating forest, and blurs the line between land and sea. This is in fact one of the great benefits of commodity-chain histories, which I think Marques is able to acknowledge, that it encourages us to follow a dynamic commodity through different kinds of spaces in a way which transcends simple analytical boundaries.

As the above suggests, commodity-chain histories can be difficult in practice, if valuable in theory. We must explain all these moving parts and complex interactions for our commodity-chain history to be useful. In the case of cod, the rise of a fishery at Newfoundland may not make sense without understanding the problems of European

\footnotetext{
${ }^{9}$ For an example, see the accounts of the James of Dunwich, a fisher-trader ship bound to Iceland in 1545. The record makes clear the continuous purchase of food and alcohol while the ship was being outfitted, and after its return. It is a reminder of the slow timescales involved with organizing a voyage, and the constant need for more inputs. Folger Shakespeare Library, L.b. 240. and Cooper (1939). See too: (PÉREZ-MALLAÍNA, 1998; MATTHEWS; ALLAIRE; HOLM, 2019).

${ }^{10}$ For a recent example of the impact of shipbuilding on forestry in an East Asian context, see Miller (2020).
} 
agriculture, the expansion of herring fisheries in the North Sea, Portuguese fishing off the coast of northwest Africa, or changes in salt production in the Bay of Biscay. Nor does it make sense without exploring the role of climate fluctuations in the northern hemisphere, changes in maritime labour recruitment and payment in coastal Europe, or evolving European ideas about the role of fish in personal health. In turn, each of these processes was deeply affected by an expansion of cod fishing. These feedback loops are essential for understanding the impact of commodity histories on global ecologies. Yet such loops are the hardest for us to trace and write about.

Hard, but not impossible. Two good examples are worth highlighting. The first Andreas Malm's Fossil Capital (2016). We could read Malm's study as a commoditychain history of coal, or even of energy itself, and an attempt to explain the rise and use of this fossil fuel in the early British industrial revolution. What makes Malm's work so powerful, however, is that in practice coal serves as an intersection point for multiple commodity histories: water, labour, land. It considers both how coal acted upon these other commodity-chains, and how the creation of a fossil-fuel economy was a continuous ecological process. The value of Malm's commodity-chain history is its ability to illuminate multiple moving parts, and explain the logic underlying their movements. The second is Jeremey Zallen's new America Lucifers (2019). Zallen explores the early evolution one commodity - artificial light - by tracing the histories of several different fuel sources. A multiplicity of individual commodities including whale oil, turpentine, lard, matches and coal, all constitute one kind of consumable natural resource, luminous energy. Zallen's work shows how these different sources of light competed with each other, both in their production and consumption. But he also shows how a single fuel source was produced by a myriad of social, economic and legal relationships. Whale oil, for instance, was shaped by the interplay between ships, maritime labour, living whales and urban populations. Turpentine depended on applying the labour of enslaved people to coastal pine forests. Together with Fossil Capital, American Lucifers can serve as a model for future work on commodity-chain histories.

\section{SCALES WITHIN AND WITHOUT NATURE}

The problem with the two examples above, Malm's Fossil Capital and Zallen's American Lucifers, is that they are localized studies (Malm in Britain, Zallen in the United States and Britain). Though they both make intricate arguments about the capitalism-nature nexus, neither purports to draw conclusions about global histories. Doing so would be difficult, for both studies pay such careful attention to particular environments and locales - the waterways of Scotland, the pine forests of North Carolina - that any attempt to go global would lose touch with the specificity that gives them such power. Even Marques' examples, drawn from the colonial Americas, point to a similar issue. The gulf between a pine tree in a New Hampshire forest or a codfish in the waters of Newfoundland, and the vast transregional world-systems in which they are embedded, is vast. This is to say nothing of the subsequent leap between world-systems and the global networks of exchange which have shaped our world for a millennium or more. Yet that is a gulf we must bridge, without losing sight of the tree or the fish along the way. This ought to make us consider the next step, the crucial step 
in Marques' intervention, which is the intellectual leap from the local to the global, from one environmental context to a world-economy.

This is important inasmuch as we need any theory of global capitalism to incorporate nature, to be a fundamentally ecological framework. For something which we treat as universal, nature is remarkably difficult for historians to treat at scale. As we zoom out the texture and specificity of the natural world, that essential quality which makes environmental history so challenging and rewarding, falls away. At the global scale we are left with tools that seem to flatten, over-abstract or even obscure natural processes. The result is that in the leap from commodities-in-nature to grand theories of historical development we find a mismatch in tools, which in turn undermines our ability to keep global economic processes embedded in the web of life (to borrow Jason Moore's formulation).

I do not think it is possible (nor, I gather, does Marques) to build an understanding of global capitalism inductively from a commodity-chain. We must have a conception of global capitalism in order to write the kinds of commodity-chain histories which have analytic power, in order to link the commodity to something greater. Our commodity-chain history must fit into a wider framework of socio-economic-ecological relations, even as it modifies and nuances this framework. Otherwise it is impossible to successfully draw wider conclusions, and our neat commodity history is left adrift. In this I can only echo the cautionary words of Paul Kershaw, who has taken the New History of Capitalism to task for precisely this problem (2020). As a consequence, it is impossible to avoid the task of linking the commodity to the wider capitalist framework.

Marques' own examples demonstrate the problems this raises in practice. It is striking that his conclusions (23-25) by and large drop the environmental context and origin of silver and ships. Instead, Marques' analysis focuses almost wholly on ships and silver as commodities in a global economy, treating them as elements in the flow of global commerce and capital. He is much more concerned with money and the flow of wealth than the impact of ships and silver on the global environment, or their relation to looming climate disasters. This certainly reflects the fact that existing scholarship emphasizes the role of silver as currency, not as nature, but nonetheless demonstrates the difficulty of making commodity-chain histories work as environmental histories.

To all this we must add a second problem, which is that commodity chains are only useful in the aggregate. The modern global economy is comprised of innumerable commodities moving through the web of life and the flow of commerce. Indeed, what terrifies us is just how much is being consumed at any one time. As if it were not difficult enough to write on the complex interactions of a single commodity-chain, we are faced with the problem of how to make it meaningful through combination with other such work. One of the most influential attempts to apply a one-commodity-chain history to global capitalism is Sven Beckert's Empire of Cotton (2015). Yet even cotton alone cannot possibly give us sufficient perspective to explain the transformation of global capitalism in the nineteenth century. Partly this is because cotton cannot be separated from the other commodities with which it interacts - coal, water, land, labour, flax, etc. Likewise, because of cotton's specific ecological requirements it can only tell us about the natural histories under capitalism of a few key biomes - the American south, the Nile River basin, northern India. In making the leap from cotton's origins to its economic impact, Beckert loses sight of nature and the web of life.

In both linking local to global and in aggregation, this issue of scale and aggregation is the Achilles' Heel of commodity-chain histories as an analytical tool. 
How do we address it? I would suggest four possible approaches, all of which are ultimately reconcilable with a renewed push for commodity-chain histories. The first and simplest solution may be to just embrace Marques' challenge, and to write more commodity histories. As we normalize this approach and expand our understanding of specific commodity-chains, we will be better prepared to integrate them together in the kind of global history of capitalism which we so desperately need.

A second solution lies in rethinking how we articulate the nature of the capitalist world-system. We must commit to understanding the world-system as an ecological relationship rather than a purely economic one. This is not a new argument - again, the nod goes to Moore (2017) - but it is one which is easier to embrace in theory than in practice. In other words, it is important for historians to start from a theoretical framework that already incorporates the environment as an inseparable part of the capitalist system. Again, this is an argument in favor of more engagement by environmental historians, and for the kind of commodity-chain histories we are discussing here.

Third, we must pay attention to how commodities are consumed, not merely in how there are produced and circulated. This has always been the trickier part of commoditychain studies, for consumption is as much about thought, culture and custom as it is about economics. This makes it much harder to trace in our sources, and requires an entirely different skill-set to understand. ${ }^{11}$ Yet consumption of any commodity is a key part of the web of life, and an inherent natural process. Eating a morsel of food or burning a piece of wood is shaped by human biological and social needs, and by our ideas about the natural world. In obscuring consumption, this is the great strength of Zallen's work, noted above, which emphasizes the way that consumption of different fuels shaped ideas about the relationship between the environment and new capitalist modes of production. It is the choice and thought of the consumer which ultimately reverberates back to shape and alter the commodity chain, and which has a profound influence on how nature is consumed at a global scale.

As a model for this kind of work, and as a study which achieves what I believe to be Marques' goal, I would suggest Christopher Otter's Diet for a Large Planet (2020). Otter's book is a series of short commodity-chain studies of wheat, beef and sugar. In combining three commodities, and tracing their mutual interactions, he builds a case for the transformative nature of food in general within the British imperial system across the nineteenth century. As Otter makes clear, the choice by British consumers to outsource their staple food production to the world at large fundamentally reorganized the economic and political relationship between the Americas, South Asia, Australia and elsewhere with the European metropole. Crucially, however, Otter frames this transformation as not merely economic and political, but as ecological. At the global scale, he makes the case for the way that changes to commodity-chains in British foodways profoundly altered the global environment, even as it was reshaping the global economic hierarchy. Britain's world-system was built on food, but in building it they altered the global environment in a way which terraformed our planet and directly led to our climate crisis.

\footnotetext{
${ }^{11}$ For recent studies which integrate consumption successfully, see: (ARCH, 2018; BREEN, 2019).
} 


\section{DON'T GO WITH THE FLOW}

The fourth and perhaps most important solution will be to shift our emphasis from flows to transformations. Commodity chains are so interesting because we can use them to trace connections and movements. Ships link ports and trading communities, silver links markets great and small, cod links old worlds to new. This is indeed the emphasis Marques puts on his own case studies, emphasizing in the end the way that silver flows through the global economy - his section title "The production of circulation" certainly emphasizes movement of this sort. The focus on flow, however, has tended to reinforce our de-emphasis on the natural and re-emphasis on the economic. Flows are easily abstracted, and tend to flatten time and distance in significant ways. Flows are also easily disentangled from nature, for flows are human constructs.

I would suggest instead that commodity-chain histories focus on transformations. These are the moments when the physical, cultural and economic properties of the commodity are changed through human action. They are the points where the links in a commodity-chain touch, rather than the chain itself.

Moments of transformation have greater potential for bridging the gaps between nature and the global economy, between the local and the world scales, than the study of movement and flows. The transformation of a commodity from one form to another is the moment when labour fuses with nature, when work is applied to a commodity to alter its form. This raises all manner of questions about labour regimes, health, social organization and coercion which are of inherent interest to scholars of capitalism. Transformations are also inherently ecological processes. It is at the moment of transformation that one commodity is combined with others (the cod with salt, the silver with mercury, the timber with pitch) to create something new through intense applications of human, animal and chemical energy. In the process, environments local and global are themselves altered. The transformation of silver from ore to coin involves chemical and organic inputs - fire from burned wood, mercury, metal minting tools, human and animal labour - which shaped the local environment in places like Potosi. In turn, the transformation of silver coins into consumable commodities, through their exchange in the marketplace, impacted everything from Yangtze delta farms to cattle herds in Britain to pearl fisheries in the Indian Ocean.

The focus on transformation allows us to deal with scale more effectively than by focusing on flow. Each act of transformation contains both the small - the physical act of changing an object from one thing to another - and the large - the set of social, economic, cultural and political pressures which guide that transformative process. At either scale it retains in nature-ness, for transformations are (as we've just seen) ecological as well as human processes. So we can study commodity-chains without separating our subjects from the web of life. When we do this, we can still think with commodities, but in important new ways. The movement of codfish from Newfoundland to the markets of Europe is less important that its transformations along the way. A live fish becomes a dead fish becomes dried food becomes a marketed good becomes a family dinner. The flow of wood in transatlantic circulation is less important than what is done to and with that forest. The transformation from a living tree to a dead tree to timber to boards to a ship to an engine of global commerce. At each of these inflection points nature, labour and time come together, allowing us glimpses of the wider workings of global capitalism. 


\section{REFERENCES}

ABU-LUGHOD, Janet L. Before European hegemony: the world system A.D. 12501350. New York: Oxford University Press, 1989.

ADELMAN, Jeremy. Is global history still possible, or has it had its moment? Aeon, 2 March, 2017. Available at: https://aeon.co/essays/is-global-history-still-possible-orhas-it-had-its-moment. Accessed: 2 Dec. 2021.

$\mathrm{ARCH}$, Jakobina K. Bringing whales ashore: oceans and the environment of early modern Japan. Seattle: University of Washington Press, 2018.

ARRIGHI, Giovanni. The long twentieth century: money, power, and the origins of our times. New and updated edition. London: Verso, 2010.

BARRETT, James H.; ORTON, David C. (ed.). Cod and Herring: the archaeology and history of medieval sea fishing. Oxford; Philadelphia: Oxbow Books Ltd., 2016.

BECKERT, Sven. Empire of cotton: a global history. New York: Alfred A. Knopf, 2015.

BOLSTER, W. Jeffrey. The mortal sea: fishing the Atlantic in the age of sail. Cambridge: Belknap Press (Harvard University Press), 2014.

BOUCHARD, Jack. Towards Terra Nova: the North Atlantic fisheries and the Atlantic World, 1490-1600. 2018. 345 p. PhD Dissertation (History) - Dietrich School of Arts and Sciences, University of Pittsburgh, 2018.

BOWES, Kim. When Kuznets went to Rome: Roman economic well-being and the reframing of Roman history. Capitalism: A Journal of History and Economics, Philadelphia, v. 2, n. 1, p. 7-40, Winter, 2021

BRAUDEL, Fernand. The Mediterranean and the Mediterranean World in the Age of Philip II. Translated by: Siân Reynolds. New York: Harper \& Row, 1972.

BRAUDEL, Fernand. Civilization and capitalism, 15th-18th century. Translated by: Siân Reynolds. New York: Harper \& Row, 1982.

BREEN, Benjamin. The age of intoxication: origins of the global drug trade. $1^{\text {st }}$ ed. Philadelphia: University of Pennsylvania Press, 2019.

BROWN, Kate. Gridded lives: why Kazakhstan and Montana are nearly the same place. The American Historical Review, Washington, v. 106, n. 1, p. 17-48, Feb. 2001.

CAMPLING, Liam; COLÁS, Alejandro. Capitalism and the Sea: the maritime factor in the making of the modern world. London; New York: Verso Books, 2021. 
COOPER, Ernest R. The Dunwich Iceland ships. The Mariner's Mirror, Greenwich, v. 25, n. 2, p. 170-177, 1, Jan. 1939.

DAVIS, Ralph. The rise of the English shipping industry in the seventeenth and eighteenth centuries. v. 48. Oxford: Oxford University Press, 2012.

DEMUTH, Bathsheba. Floating coast: an environmental history of the Bering Strait. New York: W. W. Norton \& Company, 2019.

DONAHUE, Brian. The Great Meadow: farmers and the land in colonial Concord. New Haven: Yale University Press, 2004.

GARDINER, Julie (ed.). Before the mast: life and death aboard the Mary Rose. Oxford: Oxbow Books, 2013.

HANSEN, Valerie. The year 1000: when globalization began. New York: Scribner, 2020.

HAYES, Patrick W.; MATTHEWS, J. A.; ALLAIRE, Bernard; HOLM, Poul. European naval diets in the sixteenth century: a quantitative method for comparative and nutritional analysis. Historical Methods: A Journal of Quantitative and Interdisciplinary History, London, v. 52, n. 4, p. 195-212, 30 Mar. 2019.

HEANEY, Seamus. The cure at Troy: a version of Sophocles' Philoctetes. London: Faber and Faber; Field Day, 1990.

HORDEN, Peregrine; PURCELL, Nicholas. The corrupting sea: a study of Mediterranean history. Oxford: Blackwell, 2000.

INNIS, Harold A. The cod fisheries: the history of an international economy. Toronto: Ryerson Press, 1940.

KERSHAW, Paul V. Hamlet without the Prince of Denmark: bringing capitalism back into the 'new' history of capitalism. Journal of historical sociology, Oxford, v. 33, n. 1, p. 61-73, Mar. 2020.

KURLANSKY, Mark. Cod: a biography of the fish that changed the world. New York: Walker and Co., 1997.

LOEWEN, Brad; CHAPDELAINE, Claude (ed.). Contact in the 16th century: networks among fishers, foragers, and farmers. Ottawa: University of Ottawa Press, 2016.

MADDISON, Angus. The world economy: a millennial perspective. Paris:

Development Centre Studies, OECD Publishing, 2001.

MADDISON, Angus. The world economy: historical statistics. Paris: Development Centre Studies, OECD Publishing, 2003. (Development Centre studies). 
MALM, Andreas. Fossil capital: the rise of steam-power and the roots of global warming. London: Verso, 2016.

MARQUES, Leonardo. Commodity chains and the global environmental history of the colonial Americas. Esboços, Florianópolis, v. 28, n. 49, p. 640-667, set./dez. 2021.

MANNING, Patrick. Migration in world history. London: Routledge, 2013.

MCNEILL, John R. Something new under the sun: an environmental history of the twentieth-century world. New York: W.W. Norton \& Company, 2000.

MILLER, Ian M. Fir and empire: the transformation of forests in early modern China. 1st. ed. Seattle: University of Washington Press, 2020.

MINTZ, Sidney W. Sweetness and power: the place of sugar in modern history. New York: Viking, 1985.

MOORE, Jason W. Capitalism in the web of life: ecology and the accumulation of capital. London: Verso Press, 2015.

MOORE, Jason W. The Capitalocene, Part I: on the nature and origins of our ecological crisis. The Journal of Peasant Studies, London, v. 44, n. 3, p. 594-630, 2017.

OKIHIRO, Gary Y. Pineapple culture: a history of the tropical and temperate zones. Berkeley: University of California Press, 2009. (The California world history library, v. 10)

ORTON, David C.; MORRIS, James; LOCKER, Alisson; BARRETT, James H. Fish for the city: meta-analysis of archaeological cod remains and the growth of London's northern trade. Antiquity, Cambridge, v. 88, n. 340, p. 516-530, 2015.

OTTER, Chris. Diet for a large planet: industrial Britain, food systems, and world ecology. Chicago: University of Chicago Press, 2020.

PAINE, Lincoln. The sea and civilization: a maritime history of the world. New York: Alfred A. Knopf, 2013.

PÉREZ-MALLAÍNA, Pablo E. Spain's men of the sea: daily life on the Indies fleets in the sixteenth century. Trans. by Carla R. Phillips. Baltimore: Johns Hopkins University Press, 1998.

POPE, Peter E. Fish into wine: the Newfoundland plantation in the seventeenth century. UNC Press Books, 2004.

POPE, Peter E. Early migratory fishermen and Newfoundland's seabird colonies. Journal of the North Atlantic, Steuben (ME), special volume 1: Archaeologies of the Early Modern North Atlantic, p. 57-70, 2009. 
REID, Joshua L. The Sea is my Country: the maritime world of the Makahs. New Haven: Yale University Press, 2015.

RICHARDS, John F. The unending frontier: an environmental history of the early modern world. Berkeley: University of California Press, 2006.

SCHEIDEL, Walter. Escape from Rome: the failure of empire and the road to prosperity. Princeton: Princeton University Press, 2019.

SCOTT, James C. Seeing like a state: how certain schemes to improve the human condition have failed. New Haven: Yale University Press, 1998.

SCOTT, James C. The art of not being governed: an anarchist history of upland Southeast Asia. New Haven: Yale University Press, 2009.

SICKING, Louis; ABREU-FERREIRA, Darlene (ed.). Beyond the catch: fisheries of the North Atlantic, the North Sea and the Baltic, 900-1850. Leiden; Boston: Brill, 2009. (The Northern world, v. 41).

TSING, Anna Lowenhaupt. The mushroom at the end of the world: on the possibility of life in capitalist ruins. Princeton: Princeton University Press, 2015.

TURGEON, Laurier. Codfish, consumption, and colonization: the creation of the French Atlantic World during the sixteenth century. In: WILLIAMS, Caroline A. (ed.). Bridging the early modern Atlantic World: people, products, and practices on the move. London: Routledge, 2009. p. 33-56.

WALLERSTEIN, Immanuel. Capitalist agriculture and the origins of the European world-economy in the sixteenth century. New York: Academic Press, 1974.

WESTAD, Odd Arne. The Cold War: a world history. New York: Basic Books, 2017.

ZALLEN, Jeremy. American Lucifers: the dark history of artificial light, 1750-1865. Chapel Hill: University of North Carolina Press, 2019.

\section{AUTHOR'S NOTES}

\section{AUTHOR DETAILS}

Jack Bouchard: Ph.D. Assistant Professor, Rutgers University New Brunswick, School of Arts and Sciences, Department of History, New Brunswick, NJ, USA.

\section{CORRESPONDING ADDRESS}

Rutgers University New Brunswick, Department of History, 111 Van Dyck Hall, 16 Seminary Place, New Brunswick, NJ 08901. 


\section{ACKNOWLEDGEMENTS}

With thanks to Fábio Augusto Morales for the invitation to contribute, and to Leonardo Marques for his stimulating essay. Many thanks to the anonymous readers for their helpful feedback, and the staff at Esboços for their help getting this through publication.

\section{FUNDING}

Not applicable.

\section{ETHICS COMMITTEE APPROVAL}

Not applicable.

\section{CONFLICT OF INTEREST}

There is no conflict of interest.

\section{LICENSE OF USE}

(C) Jack Bouchard. This article is licensed under the Creative Commons License CC-BY. With this license, you can share, adapt, create for any purpose, as long as the authorship is properly attributed.

\section{PUBLISHER}

Universidade Federal de Santa Catarina. Graduate Program in History. UFSC Journal Portal. The ideas expressed in this article are the sole responsibility of its authors, and do not represent, necessarily, the opinion of the editors or the University.

\section{EDITORS}

Fábio Augusto Morales

Flávia Florentino Varella (Editor-in-chief)

\section{HISTORY}

Received on: May 27, 2021.

Approved on: December 1, 2021.

How to cite: BOUCHARD, Jack. Making the leap: commodity chains and the potential for global environmental histories of capitalism. Esboços, Florianópolis, v. 28, n. 49, p. 698-715, Sept./Dec. 2021. 